or leadless glazes had become so widespread that it was considered practicable to prohibit the use of any glaze that was not either leadless or of low solubility. This was not an easy requirement for all firms to comply with, and the glazed tile industry was faced with a particularly difficult problem. Intensive research enabled all firms to be in a position to comply with the requirement when it became law. The other source of lead poisoning was the colour used in decorating the ware. Higher standards of cleanliness and improved methods of dust control have, so far, dealt with this hazard, with the satisfactory result that in recent years lead poisoning has virtually been eliminated from the industry.

Another major achievement of the industry, this time in reducing the risk of pneumoconiosis, has been the substitution of alumina for powdered flint in the placing of china for the biscuit fire. When it became clear that alumina was a satisfactory alternative, the china industry, in spite of some technical problems involved, agreed that the flint should be replaced by alumina. By 1947, when this change was made compulsory, all firms in the industry had in fact changed over.

Work on the control of dust in the making processes, where there is a health hazard from pneumoconiosis, is continuing. For some years the British Ceramic Research Association has been working on the dust problems of the industry, and has done much valuable research work into the behaviour and control of dust given off in certain processes. The Research Association has already designed dust-control plant for the processes of towing and hollow-ware fettling which is proving most effective. Work is in progress on the control of dust in the dust tile-making processes, and to determine the most suitable material for workers' overalls where there is need to protect them against dust.

To provide a continuing forum for discussion of the health and safety problems of the industry, the Chief Inspector of Factories in 1956 appointed a Joint Standing Committee of the Pottery Industry. With the help of the British Ceramic Research Association, it has published an advisory booklet on dustextraction in the pottery industry. It has also directed the attention of industry to the dangers inherent in the use of hydrofluoric acid in cleaning gold, encouraging the use of other methods which it has made known.

The aim of the survey was to present an objective picture of existing conditions in the industry and to indicate outstanding problems. The visits made by the inspectors have been followed up by action to secure improvements. The work that requires to be done in order to deal with outstanding problems is under examination by the Joint Standing Committee (H.M.S.O., 5s.).

\title{
DEVELOPMENTS IN TRAINING
}

A SERIES of five papers on training were given at the Polytechnic, Regent Street, to an audience of two hundred directors and industrial executives during January and February, 1957. They have now been reprinted and form a valuable addition to the scanty information available for those concerned with all aspects of training in industry*.

The first, by Prof. J. Z. Young, deals with the fundamental aspects of learning by drawing on biological studies of organisms at all levels of complexity. Developing the importance of perception in learning, W. D. Seymour, of the Department of Engineering Production in the University of Birmingham, produces evidence to show that carefully devised training procedures for manual skills which take

- New Developments in Training: Five Studies in the Efficient Communication of Skills. Edited by Frank A. Heller. (New Development Series No. 3.) Pp. 80. (London: Polytechnic Management Association, 1959.) $5 s$. account of recent findings will usually halve the normal learning period. In the third lecture, Mrs. W. Raphael, assistant director of the National Institute of Industrial Psychology, describes the in-plant training being carried out in seven European countries and shows that the training provided for operatives exists largely in name only. F. A. Heller, head of the Department of Management Studies at the Polytechnic, shows how the development of managerial skills can be approached from the same biological and analytical points of view as any other skill training. Like other lectures in the series, he pays special attention to the methods rather than to the content of training programmes. The fifth lecture was given by S. D. M. King, director of Organization and Training, Ltd., who used case-studies to illustrate the importance of relating training to a carefully devised policy at all levels of an organization.

\section{ERGONOMICS}

$\mathrm{T}$ THE development of modern industry with the substitution of mechanization for craftsmanship has brought new problems ; the machine has reached the point where it is no longer the limiting factor in production and this in turn is imposing new stresses and strains on the operator, who can no longer be left to get along as best he can. That this was beginning to happen began to be realized about fifty years ago, and early developments in fitting the job to the man, like the motion study of Gilbreth, were part of scientific management for increasing production through reduction of fatigue. Men of the biological sciences began to become aware that people at work were worthy of study and that remarkably little was known about their capabili. ties and aspirations.

It took the added stress of two world wars to stimulate any real interest. A start was made in the First World War when groups of physiologists and psychologists such as the Industrial Fatigue Research Board in the United Kingdom started work. Between the wars progress was slow, perhaps because a general 
labour surplus removed a demand for maximum economy in use of labour ; but during and since the second World War the research effort has been vastly intensified. Much of it gained its initial impetus from the armed forces and has, particularly in the United States, continued to be supported by them. In other countries research has been much more directed towards solving industrial problems, as typified by that done by work physiologists in Sweden and Germany.

The fragmentation of the subject into a number of disciplines independently studying human work could not continue indefinitely, and the first fusion oecurred in the United Kingdom in 1949 with the formation of an interdisciplinary society and the coining of the term 'ergonomics' to cover the study of human work. Although the British society attracted adherents from all over the world it soon became clear that a truly international meeting was needed. The initiative was taken by the European Productivity Agency in the form of Project 335, the final aim of which is a tripartite international conference of scientists, employers and employees. As a preparation for this, two preliminary steps wer's taken. The first was to send a mission to the United States to report on the situation there, and the second was to hold a technical seminar to assemble information on progress in Europe. A report has now been issued, part one of which contains the report of the mission and part two a report on the seminar*. The tripartite conference has still to take place. *"Fitting the Job to the Worker. A Survey of American and
Guropzan Working Conditions in Industry" (Paris, O.E.E.C., 14s.).

\title{
AN OCEANOGRAPHIC SURVEY OF THE ROSS SEA
}

\author{
By J. S. BULLIVANT \\ New Zealand Oceanographic Institute, Department of Scientific and Industrial \\ Research, Wellington, New Zealand
}

\begin{abstract}
IN January 1959 an oceanographic survey of the Ross Sea was carried out by members of the New Zealand Oceanographic Institute, from the New Zealand Antarctic Supply Ship H.M.N.Z.S. Endewvour.

The route taken by the Endeavour and the distribution of the twenty-four stations occupied are shown in Fig. 1. A brief station list is also included, particularly for the information of workers planning investigations in the area in the near future.

The aim of the survey was to investigate the hydrology, the benthic fauna and the marine sedinents in the area.

The routine procedure at each station was to lower a bathythermograph $(275 \mathrm{~m}$.) and a cast of reversing bottles, make a vertical plankton haul from near the
\end{abstract}

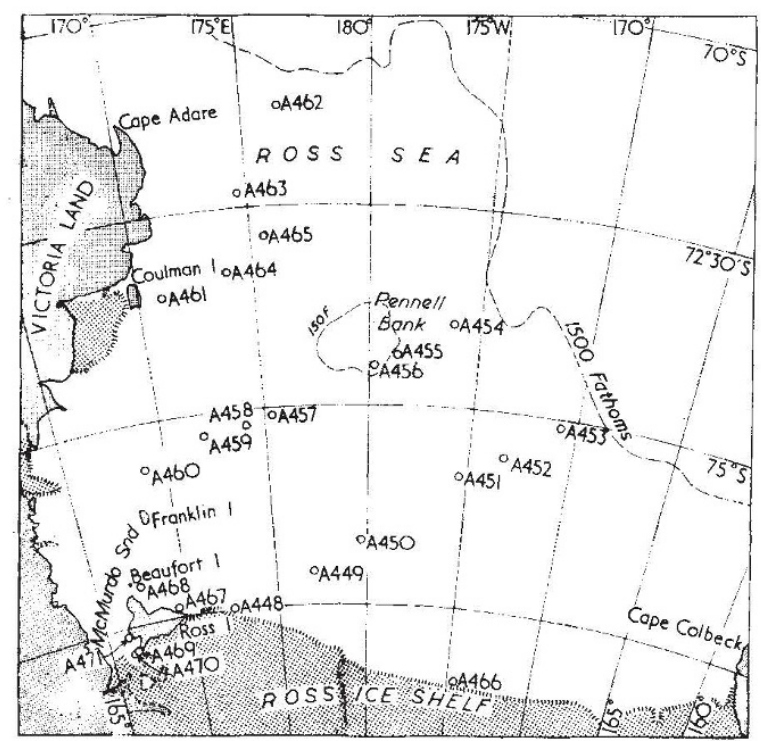

Fig. 1. Ross Sea, Antarctica, showing stations occupied from bottom to the top, collect phytoplankton, make three lowerings with a twin orange-peel grab sampler and collect epifauna from the bottom with a trawl. The grab sampler consisted of two modified four-blade orange-peel grabs, each having a bucket capacity of 24.5 litres, suspended one at each end of a 4 - ft. bar.

In addition to these routine observations, surface water samples from stations $A 466$ and $A 470$ and a bottom water sample from $A 470$ were obtained for determination of carbon-14 activity in order to study water movements in the Ross Sea and under the Ross Ice Shelf.

An underwater-camera and a bottom trawl were used at three stations $(A 468, A 469$ and $A 471)$ near Ross Island, to sample three different types of bottom community. Some of the photographs

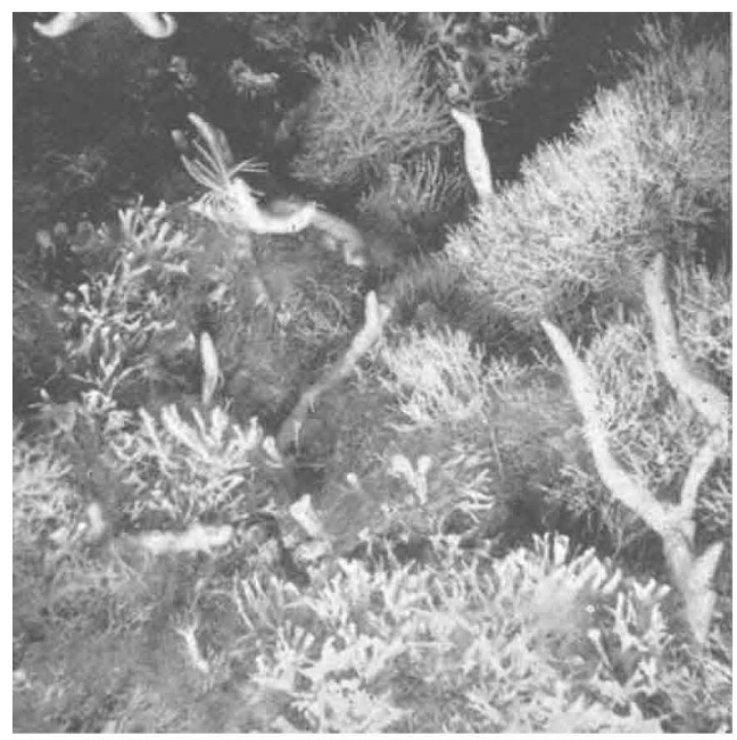

Fig. 2. Bottom photograph from station A468; sponges, coelenterates and bryozoans predominate. Note crinoid top left.
(Depth, $110 \mathrm{~m}$. ; foreground, $0 \cdot 75 \mathrm{~m}$. wide; depth of fleld, $1 \mathrm{~m}$.) 